Jurnal Media Pertanian Vol. 1 No. 2 Tahun 2016 Hal. 78 - 84

Media Komunikasi Hasil Penelitian dan Review Literatur Bidang Ilmu Agronomi ISSN $2503-1279$

\title{
PENGAMATAN BEBERAPA PENYAKIT yang MENYERANG TANAMAN KOPI (Coffea Sp) di DESA MEKAR JAYA KECAMATAN BETARA KABUPATEN TANJUNG JABUNG BARAT
}

\author{
Yuza Defitri \\ Program Studi Agroteknologi, Fakultas Pertanian Universitas Batanghari \\ Jl. Slamet Riyadi-Broni, Jambi 36122 Telp. +62074160103 \\ email : yuzadefitri@yahoo.com
}

\begin{abstract}
The research about the observation of diseases that attack Coffee plants (Coffea sp.) in Mekar Jaya village Betara subdistrict Tanjung Jabung Barat Regency, and Agriculture Quarantine Laboratory Jambi had been done for six months. The aim of this research is to identification the disease that attack coffee plants. The research was conducted by observing the disease which in coffea plants area, and identificaton pathogenic fungi in laboratory by moist chamber method using microscop and also fungi identifications book. The result of this research showed that there were three pathogenic fungies which attack Coffee plants namely: 1) Hemileia sp wich caused coffee leaft rust disease, 2) Cercospora coffeicola wich caused Brown eye-spot disease, and 3) Upasia salmanicolor wich caused Upas fungi disease.
\end{abstract}

Keywords : Pathogenic fungi, Cooffee Plants Disease, Coffee Plants.

\begin{abstract}
Abstrak
Penelitian tentang pengamatan beberapa penyakit yang menyerang tanaman Kopi (Coffea sp) di desa Mekar Jaya kecamatan Betara kabupaten Tanjung Jabung Barat dan di Laboratorium Karantina Pertanian Jambi telah dilakukan selama 6 bulan. Tujuan penelitian adalah untuk mengetahui penyakit yang menyerang tanaman kopi. Penelitian dilakukan dengan mengamati gejala penyakit di lapangan dan mengidentifikasi jamur patogen di laboratorium secara moist chamber dengan menggunakan mikroskop dan buku identifikasi jamur. Hasil penelitian menunjukkan bahwa ditemukan tiga jamur patogen yang menyerang tanaman kopi yaitu: 1). Hemileia sp penyebab penyakit Karat Daun 2) Cercospora coffeicola penyebab penyakit Bercak Daun, 3) Upasia salmanicolor penyebab penyakit Jamur upas.
\end{abstract}

Kata Kunci : Jamur Patogen, Penyakit tanaman kopi, Tanaman kopi

\section{PENDAHULUAN}

Kopi (Coffea $s p$ ) adalah species tanaman berbentuk pohon yang termasuk dalam famili Rubiaceae dan genus Coffea. Tanaman ini tumbuhnya tegak, bercabang, dan bila dibiarkan tumbuh dapan mencapai tinggi $12 \mathrm{~m}$. daunnya bulat telur dengan ujung agak meruncing. daun tumbuh berhadapan pada batang, cabang, dan ranting-rantingnya. Kopi mempunyai sistem percabangan yang agak berbeda dengan tanaman lain. tanaman ini mempunyai beberapa jenis cabang yang sifat dan fungsinya agak berbeda (Wijaya, 2008). 
Jurnal Media Pertanian Vol. 1 No. 2 Tahun 2016 Hal. 78 - 84

Media Komunikasi Hasil Penelitian dan Review Literatur Bidang Ilmu Agronomi ISSN $2503-1279$

Kopi merupakan salah satu hasil komoditi perkebunan yang memiliki nilai ekonomis yang cukup tinggi diantara tanaman perkebunan yang lainnya dan berperan penting sebagai sumber devisa Negara. Kopi tidak hanya berperan penting sebagai sumber devisa melainkan juga merupakan sumber penghasilan bagi bagi tidak kurang dari satu setengah juta jiwa petani kopi di Indonesia (Rahardjo, 2012).

Saat ini Indonesia menjadi produsen utama kopi ke tiga setelah Brasil dan Vietnam. Luas tanaman kopi di Indonesia 1.292.965 ha (tahun 2011) dengan produksi 633.991 ton dan sekitar 96\% diusahakan oleh rakyat. Kopi Indonesia tergolong dalam dua jenis kopi yaitu kopi Arabika dan kopi Robusta. Keunggulan kopi Arabika adalah kopi ini mempunyai cita rasa yang bersifat khas sehingga pasarnya pun khusus, sedangkan kopi robusta merupakan salah satu komoditas yang memiliki nilai strategis dalam rangka pemberdayaan ekonomi rakyat. Prospek komoditi kopi Indonesia sangat besar karena didukung adanya ketersediaan lahan pengembangan kopi serta Indonesia memiliki keunggulan geografis dan iklim yang menghasilkan kopi yang mempunyai cita rasa dan aroma yang digemari masyarakat dunia. Provinsi Jambi merupakan daerah yang banyak melakukan usaha budidaya tanaman kopi. Luas areal penanaman kopi robusta 25.186 ha dengan produksi 12.987 Ton, kopi arabika 565 ha dengan produksi 103 ton (Dinas Perkebunan Provinsi Jambi, 2012). Menurut Dinas Perkebunan Tanjung Jabung Barat tahun 2013, di kabupaten Tanjung Jabung Barat tanaman kopi dibudidayakan seluas 2651,8 ha dan produksi 1661,8 ton.

Salah satu penyebab rendahnya produksi tanaman kopi tersebut adalah karena terserang penyakit, Penyakit sering menimbulkan kerugian yang cukup berarti pada tanaman kopi. Setiap tahun kerugian yang ditimbulkan bisa mencapai jutaan rupiah setiap hektar tanaman kopi. Penyebab penyakit yang sering dijumpai pada tanaman kopi adalah jamur. Sedangkan bakteri atau virus jarang dijumpai dan tidak menimbulkan kerusakan yang berarti (Semangun, 1990 ).

Berikut ini ada beberapa jenis penyakit yang menyerang kopi di perkebunan yaitu, penyakit karat daun (Hemileia vastatrix), penyakit busuk buah kopi, penyakit Bercak daun kopi, penyakit Jamur upas.

Penyakit tanaman di lapangan dapat dikenali berdasarkan tanda dan gejala penyakit. Tanda penyakit merupakan bagian mikroorganisme patogen yang dapat diamati dengan mata biasa yang mencirikan jenis penyebab tersebut. Misalnya miselia yang berbentuk seperti kapas, merupakan salah satu tanda jamur patogen yang menginfeksi tanaman tersebut. Gejala pada umumnya sangat spesifik tergantung pada spesies yang menginfeksinya, sehingga gejala penyakit tersebut dapat dipergunakan untuk mengidentifikasi jenis patogen yang menginfeksi di lapangan (Agrios, 1999).

Penyakit tanaman dapat mengakibatkan kerugian baik secara kuantitas maupun kualitas hasil panen. Upaya untuk mengurangi kerugian akibat infeksi penyakit tanaman tersebut dapat dilakukan pengendalian dengan sasaran dan cara yang tepat. Pengamatan yang dini dan identifikasi penyakit yang tepat akan menjamin keberhasilan pengendalian (Abadi,2005). 
Jurnal Media Pertanian Vol. 1 No. 2 Tahun 2016 Hal. 78 - 84

Media Komunikasi Hasil Penelitian dan Review Literatur Bidang Ilmu Agronomi ISSN $2503-1279$

Untuk peningkatan produksi tanaman kopi perlu diketahui keadaan tanaman kopi tersebut bagaimana pertumbuhannya, apakah terserang penyakit atau tidak. Hal ini berguna untuk melakukan teknik pengendalian penyakit pada tanaman kopi.

Berdasarkan hal tersebut maka akan dilakukan penelitian tentang identifikasi penyakit pada tanaman kopi yang disebabkan oleh jamur patogen. Identifikasi ini dilakukan dengan cara pengamatan secara makro yaitu gejala di lapangan serta secara mikro di laboratorium. Dengan mengidentifikasi penyakit ini kita dapat mengetahui jenis penyakit serta patogen penyebab penyakit dan sehingga dapat ditentukan teknik pengendalian penyakit tanaman kopi tersebut.

\section{METODE PENELITIAN}

Penelitian ini dilaksanakan di desa Mekar Jaya kecamatan Betara kabupaten Tanjung Jabung Barat dan Laboratorium Karantina Pertanian Kelas I Jambi selama 6 bulan, mulai bulan Maret sampai bulan Agustus 2016.

Penentuan daerah pengamatan di lapangan dilakukan dengan metode Simple Random Sampling. Pengambilan sampel tanaman dilakukan secara acak di perkebunan kopi rakyat. Masing-masing areal dilakukan pengamatan terhadap tanaman kopi yang terserang penyakit yang disebabkan oleh jamur patogen. Kemudian diambil bagian tanaman yang terserang dan dibungkus dalam koran lembab dan simpan di kantong plastik untuk dibawa ke laboratorium untuk diidentifikasi .

Isolasi jamur dari bagian tanaman kopi yang terserang penyakit di lapangan dilakukan dengan cara moist chamber, sampel tanaman dipotong kecil kira-kiran $1 \mathrm{~cm}$, dibilas dengan aquades dan diletakkan di atas kertas saring lembab dalam petridish. Kemudian diinkubasi selama 2 × 24 jam. Setelah itu diamati miselia jamur yang tumbuh. Jamur yang tumbuh diambil dengan jarum ose dan dipindahkan ke dalam media PDA yang telah disiapkan dalam petridish, kemudian diinkubasikan selama 2 × 24 jam. Setelah diinkubasi diamati dengan mikroskop untuk mengidentifikasi jenis jamur yang menyerang menggunakan buku identifikasi jamur.

Pengamatan di lapangan meliputi : Melihat gejala penyakit yang menyerang tanaman kopi khususnya gejala yang disebabkan jamur patogen baik pada daun, batang, akar dan bagian tanaman lainnya. 


\section{HASIL dan PEMBAHASAN}

Hasil pengamatan secara makroskopis terhadap penyakit yang menyerang tanaman kopi di desa Mekar Jaya Betara Tanjung Jabung Barat adalah seperti terlihat pada gambar berikut ini :

\section{Gejala Penyakit Karat Daun Kopi (Hemileia vastatrix)

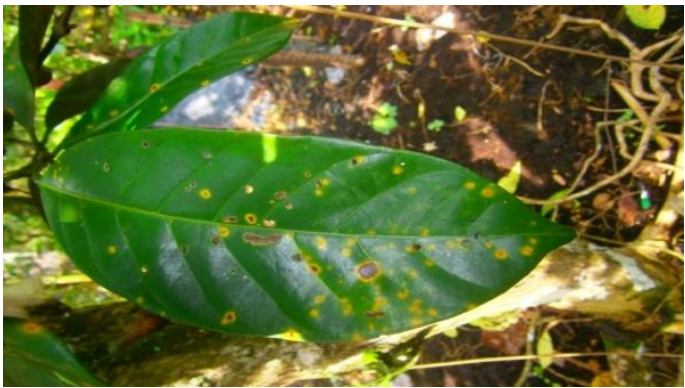 \\ Gambar 1. Gejala Penyakit Karat Daun Kopi (Hemileia vastatrix)}

Gejala penyakit yaitu pada sisi bawah daun terdapat becak-becak yang semula berwarna kuning muda, kemudian menjadi kuning tua, terbentuk tepung berwarna jingga cerah yang terdiri dari urediospora jamur Hemilea vastarix (Semangun, 1990). Menurut Agrios (1999) pada serangan berat pohon tampak kekuningan, daunnya gugur akhirnya pohon menjadi gundul.

Jamur membentuk spora dalam jumlah banyak kemudian terjadi penetrasi ke dalam jaringan daun. Infeksi terjadi melalui permukaan bawah daun. Perkecambahan spora memerlukan air. Lama waktu perkecambahan tergantung dari suhu. Pada suhu optimum 2115Celcius diperlukan waktu 1-3 jam untuk berkecambah.

Faktor yang mempengaruhi perkembangan patogen yaitu, air berperan dalam penyebaran penyakit, angin berperan dalam penyebaran spora,umur daun menentukan kerentanan terhadap penyakit, dan pohon atau cabang yang berbuah lebat lebih rentan.

Pengendalian penyakit meliputi, penggunaan varietas kopi yang tahan,penggunaan mikrobia yang bersfat berlawanan, yaitu bakteri Bacillus thuringienesis dan jamur Verticilium hemileia, dan menggunakan fungisida.

\section{Gejala Penyakit Bercak Daun Kopi (Cercospora coffeicola).}

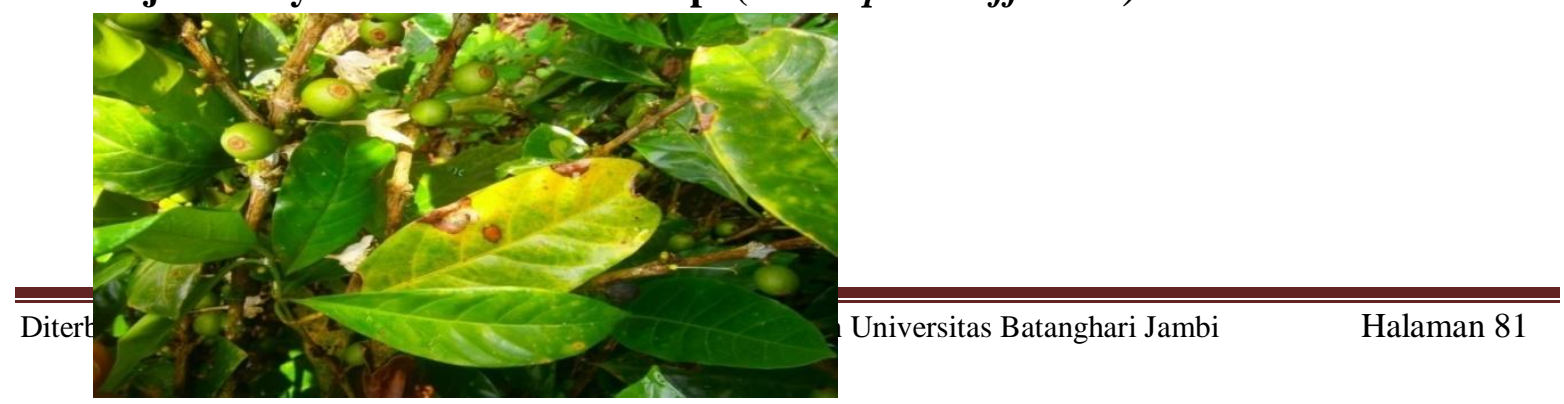


Jurnal Media Pertanian Vol. 1 No. 2 Tahun 2016 Hal. 78 - 84

Media Komunikasi Hasil Penelitian dan Review Literatur Bidang Ilmu Agronomi ISSN $2503-1279$

Gambar 2. Gejala Bercak Daun Kopi (Cercospora coffeicola).

Becak daun kopi disebabkan oleh jamur Cercospora coffeicola. Pada daun-daun terdapat becak-becak bulat berwarna coklat kemerahan atau coklat tua, berbatas tegas dan agak mengendap. Pada becak yang tua terdapat pusat yang berwarna putih kelabu, yang sering tampak ditaburi tepung hitam yang terdiri dari konidium jamur (Semangun, 1990).

\section{Gejala Penyakit Jamur Upas (Upasia salmanicolor)}

Penyakit jamur upas disebabkan oleh jamur Upasia salmanicolor. Basidiospora tidak berwarna, berbentuk jambu/ buah pir dengan ujung runcing. Basidium berbentuk gada, piknidium berwarna merah bata kadang-kadang jingga, benyak mempunyai konidium jorong yang tidak beraturan,

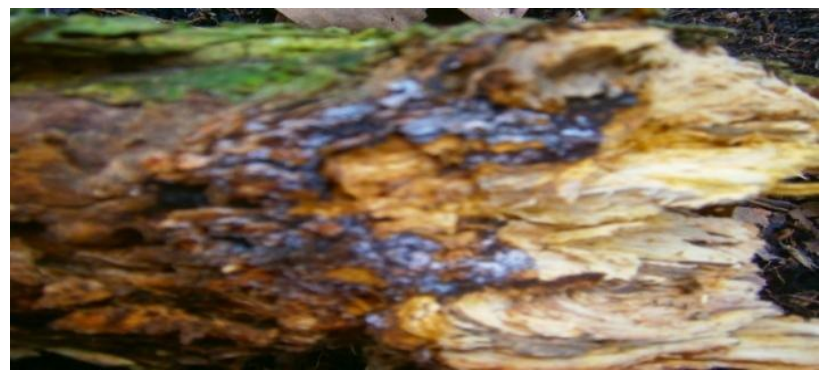

Gambar 3. Gejala Penyakit Jamur Upas (Upasia salmanicolor)

Gejala penyakit jamur Upas yaitu : 1) infeksi terjadi pada percabagangan atau sisi bawah cabang dan ranting. Mula-mula jamur membentuk miselium tipis, mengkilat seperti sutera atau perak, disebut stadium rumah laba-laba, pada stadium tersebut belum masuk kedalam kulit, 2) Pada bagian ranting yang tidak terlindung, stadium rumah laba-laba berkembang menjadi stadium bongkol kemudian membentuk banyak sporodakium berwarna merah, disebut stadium anamorf

Hasil pengamatan secara mikroskopis terhadap penyakit tanaman kopi di Laboratorium Karantina Pertanian Kelas I Jambi ditemukan ada tiga jenis jamur. Setelah diidentifikasi, jamur tersebut diduga adalah sebagai berikut :

\section{Jamur Hemileia sp}

Jamur yang menyebabkan penyakit karat daun pada tanaman kopi adalah Hemileia vastatrix pada umumnya adalah parasit obligat, yang hanya dapat hidup jika memarasit jaringan hidup (Semangun, 1990).

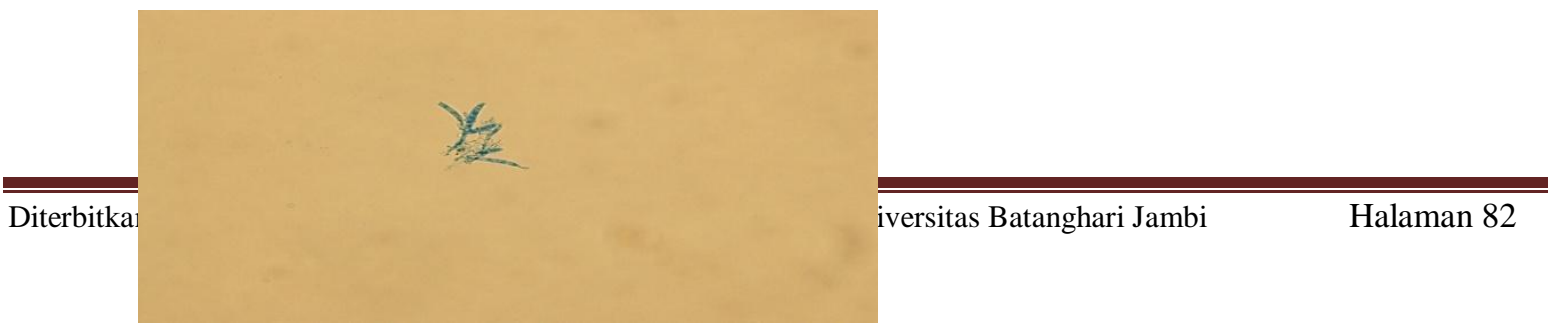




\section{Gambar 4. Konidia Hemilleia sp}

Pada $H$. vastatrix ini spora yang memegang peranan penting dalam pembiakan dan pemencarannya adalah urediospora yang dibentuk dalam jumlah yang besar. Urediospora membentuk pembuluh kecambah yang seterusnya membentuk apresorium di depan mulut kulit, dan seterusnya jamur mengadakan penetrasi ke dalam jaringan daun (Semangun, 1990).

\section{Jamur Cercospora coffeicola}

Konidium Jamur Cercospora coffeicola berbentuk gada, bersekat. Serangan Cercospora pada daun-daun sangat dibantu oleh kelembaban udara yang tinggi, misalnya terjadi pada musim hujan, di persemaian yang terlalu gelap, pemberian peteduh yang terlalu rimbun, dan pertukaran udara yang kurang (Agrios, 1999).

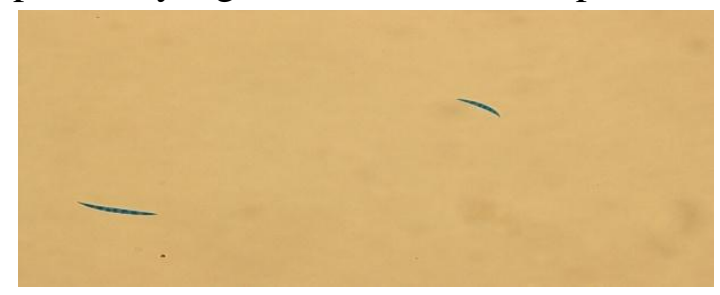

Gambar 5 . Konidia Jamur Cercospora coffeicola

3. Jamur Upas (Upasia salmanicolor)

Jamur upas adalah jamur polifag (dapat memarasit banyak tumbuhan) dan tercatat mempunyai lebih dari 140 tanaman inang. Selain kopi jamur upas dapaat menyerang karet, teh, kakao dll.

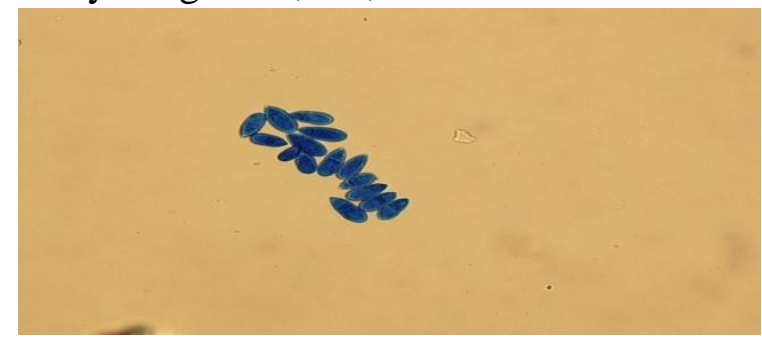

Gambar 6 . Konidia Jamur Upasia salmanicolor

Basidiospora jamur berbentuk gada, mempunyai banyak konidium jorong tidak teratur. Ukuran konidium tidak teratur (Agrios, 1999). 
Jurnal Media Pertanian Vol. 1 No. 2 Tahun 2016 Hal. 78 - 84

Media Komunikasi Hasil Penelitian dan Review Literatur Bidang Ilmu Agronomi ISSN $2503-1279$

Menurut Semangun (1990) jamur ini banyak menyerang di kebun-kebun yang lembab, antara lain yang pemangkadannya kurang dan pohon pelindung terlalu berat. Penyakit banyak terdapat pada daearah yang curah hujannya tinggi.

Dari ketiga macam penyakit yang ditemukan di lokasi penelitian dapat ditentukan cara pengendalian penyakit tersebut secara umum, yaitu :

a. mengurangi kelembaban kebun dengan memangkas pohon pelindung atau dengan mengurangi ranting-ranting kopi yang tidak produktif.

b. membersihkan sumber infeksi yang ada di sekitar areal perkebunan kopi.

c. jika penyakit belum meluas, bagian-bagian daun sakit digunting, daun yang gugur dikumpulkan dan dibakar atau dibenamkan.

d. pemberian fungisida yang tepat untuk sasaran jamur tersebut.

\section{KESIMPULAN}

Dari hasil penelitian yang telah dilakukan, dapat diidentifikasi 3 jamur penyebab penyakit tanaman kopi yaitu :

1) Jamur Hemileia sp penyebab penyakit karat daun kopi (Hemileia vastatrix).

2) Jamur Cercospora coffeicola penyebab penyakit bercak daun kopi (Cercospora coffeicola).

3) Jamur upas (Upasia salmanicolor) penyebab penyakit jamur upas (Upasia salmanicolor).

\section{DAFTAR PUSTAKA}

Abadi, A. 2005. Ilmu Penyakit Tumbuhan. Ilmu Penyakit Tumbuhan. Bayu Media Jakarta

Agrios, G. 1999. Ilmu Penyakit Tumbuhan. Gajah Mada University Press Jogyakarta.

Annisa. 2013. Kopi dan Variannya. http kopi dan variannya (online), diakses tanggal 16 Maret 2013.

Anonymaus, 2011. http:// Wikipedia.org/wiki/gejala

Barnet, H. 1988. Inperfect Fungi. Bergess Publishing Company, Virginia.

Dinas Perkebunan Provinsi Jambi. 2012. Luas Dan Produksi Tanaman Perkebunan Menurut Jenis Tanaman. Jambi.

Dinas Perkebunan Kabupaten Tanjung Jabung Barat. 2013. Luas Dan Produksi Kopi Liberika. Tanjung Jabung Barat.

Edi P. 2011. Buku Pintar Kopi. PT. Agro Media Pustaka. Jakarta.

Najiyanti,S dan Dinarti. 2004. Budidaya Tanaman Kopi dan Penanganan Pasca Panen. Penebar Swadaya. Jakarta.

Raharjo. P. 2012. Panduan Budidaya dan Pengolahan Kopi Arabika dan Robusta. Penebar Swadaya. Jakarta.

Semangun, H. 1990. Penyakit Tanaman Kebun di Indonesia. Gajah Mada University Press Jogyakarta.

Sinaga, M. 2004. Dasar-dasar Ilmu Penyakit Tumbuhan. Penebaran Swadaya Jakarta. 
Jurnal Media Pertanian Vol. 1 No. 2 Tahun 2016 Hal. 78 - 84

Media Komunikasi Hasil Penelitian dan Review Literatur Bidang Ilmu Agronomi ISSN $2503-1279$

Wijaya. 2000. Statistika Non Parametrik ( Aplikasi Program SPSS ). Alfabeta. Bandung

Wijaya. K. 2008. Biologi Dan Ekologi Tanaman Kopi. Agromedia Pustaka, Yogyakarta. 